\title{
TO STUDY THE ANTIBACTERIAL ACTIVITY OF VARIOUS EXTRACTS OF CLAUSENA DENTATA (WILLD.) ROEM.
}

\author{
ANNAMALAI MADURAM ${ }^{1 *}$, RAJU KAMARAJ ${ }^{2}$ \\ ${ }^{1}$ Department of Pharmacology, Shri Sathya Sai Medical College and Research Institute, Sri Balaji Vidyapeeth - Deemed to be University, \\ Kancheepuram, Tamil Nadu, India. ${ }^{2}$ Department of Pharmacognosy, SRM College of Pharmacy, SRM Institute of Science and Technology, \\ Chennai, Tamil Nadu, India. Email: maduramraj@gmail.com
}

Received: 04 September 2019, Revised and Accepted: 09 November 2019

ABSTRACT

Objectives: The objectives of the study were to study the antibacterial activity for the various extracts of Clausena dentata against human pathogens. Clausena (Rutaceae) is a genus of about 23 species of unarmed trees and shrubs. The stem bark of $C$. dentata is used in veterinary medicine for the treatment of wounds and sprains. Even though $C$. dentata has a lot of potential medical uses, the study of microbiological properties is very scarce.

Methods: The plant $C$. dentata was collected from Kadagaman, near Tiruvannamalai, Tamil Nadu, India, and authenticated by Centre for Advanced Study in Botany, University of Madras, Chennai. The dry powder of stem bark was extracted with hexane, chloroform, and methanol. The extracts were subjected to qualitative phytochemical screening and antibacterial activity against human pathogenic bacteria such as Escherichia coli, Salmonella Typhi, Klebsiella pneumonia, Vibrio cholerae, and Staphylococcus aureus and compared with ciprofloxacin.

Results: Qualitative chemical tests revealed the presence of various phytochemicals such as alkaloids, glycosides, carbohydrate, proteins and amino acids, phytosterols, and volatile oil. The antibacterial activity result reveals that all the extracts were are more active against $V$. cholerae. The activity against Pseudomonas aeruginosa was mild.

Conclusion: The activity against $V$. cholerae was comparable with that of $5 \mu \mathrm{g} / \mathrm{mL}$ ciprofloxacin at the concentration of $C$. dentata $40 \mu \mathrm{g} / \mathrm{mL}$. The orders of antibacterial activity against human pathogenic bacteria are hexane, methanol, and chloroform extract of $C$. dentata.

Keywords: Clausena dentata, Antibacterial activity, In vitro, Disc diffusion, Extracts.

(c) 2020 The Authors. Published by Innovare Academic Sciences Pvt Ltd. This is an open access article under the CC BY license (http://creativecommons. org/licenses/by/4. 0/) DOI: http://dx.doi.org/10.22159/ajpcr.2020.v13i1.35553

\section{INTRODUCTION}

The family Rutaceae consists of about 140 genera and 1300 species. These plants are aromatic trees, shrubs, and few herbs and are distributed throughout the warm and temperate regions of the world, being most abundant in South Africa and Australia. The aroma of the plant is due to the universal occurrence of lysigenous oil cavities in the leaves and other young organs. A number of plants of Rutaceae are of medicinal value and furnish several drugs and pharmaceutical products. Pilocarpine (used in the treatment of glaucoma) from Pilocarpus jaborandi and diosphenol (used in the treatment of diuretic) from Barsoma betulina are the bestknown drugs. Essential "oil of Bergamot" and "oil of Rue" used in perfumery and medicine, respectively, are extracted from Citrus species and Ruta graveolens. Clausena (Rutaceae) is a genus of about 23 species of unarmed trees and shrubs mainly grow in Indo-Malayan with a few in China, Africa, and Australia. Ten species are known to grow in India, of which five are of economic importance. The stem bark of Clausena dentata is used in veterinary medicine for the treatment of wounds and sprains [1]. The dried powdered rootstock is also used by the Kols, the tribes in Chotanagpur region, India, for decayed teeth. In Cambodia, the stem is considered bitter tonic and astringent [2].The infusion is given for colic pain with diarrhea. C. dentata is used for digestion and as diuretic. $\alpha$-, $\beta$ - and $\gamma$-clausenans and diclausenan have been reported from the leaves of $C$. dentate [3]. Imperatorin and two new coumarins, dentatin and nordentatin, have been isolated from the root bark [4]. Even though C. dentata has lot of potential medical uses, the study on chemistry of the plant is very scarce [5]. Considering the importance of the plant, the present study was undertaken with the following objectives: To test the efficacy of the extracts and isolated compounds as antibacterial agents against human pathogens. There are reports on efficacies of pure coumarins against Gram-positive and Gram-negative bacteria as well as fungi. Free $60 \mathrm{H}$ in the coumarin nucleus has been found to be important for antifungal activity, while the free hydroxyl group at position 7 is important for antibacterial activity. Interestingly, coumarins also have inhibitory effect on DNA gyrase which may be linked to the anti-human immunodeficiency virus activity [6]. Antimalarial activity has been addressed to daphnetin, extracted from the plants of the genus Daphne [7] as well as dentatin and clausarin isolated from Clausena harmandiana [8]. The organisms that are clinically important and used in this study to find out the antibacterial activity of this plant are listed below along with the common diseases which they cause in human [9]. Antibiotic has been defined by Hammond and Peter [10] as "chemical substances that are produced by microorganisms antagonistic to the growth or life of other microorganisms at high dilution." Ciprofloxacin is used in this study to compare the inhibitory effect of the extracts/isolated compounds on the human pathogenic bacteria. It is the most potent firstgeneration fluoroquinolone antibiotic active against a broad range of bacteria. The "first-generation" fluoroquinolones were introduced in the 1980s. The minimum inhibitory concentration of ciprofloxacin against microorganisms is usually $<0.1 \mu \mathrm{g} / \mathrm{mL}$. It is rapidly absorbed orally, effective in a broad range of infections including some difficult to treat ones. Due to wide-spectrum bactericidal activity, oral efficacy, and good tolerability, it is being extensively employed for a wide therapy of infections.

\section{METHODS}

\section{Plant collection}

The plant $C$. dentata (Willd.) Roem. was collected from Kadagaman, near Tiruvannamalai, Tamil Nadu, India, and the identification was confirmed as C. dentata at Centre for Advanced Study in Botany, University of Madras, Chennai. A voucher specimen of the plant has been deposited at the herbarium. The collected plant material was free from disease and also free of contamination of other plants. 


\section{Preparation of extracts}

The dry powder of stem bark $(2.5 \mathrm{~kg})$ was first soaked, at room temperature, in hexane $(1: 4 \mathrm{w} / \mathrm{v})$ for $24 \mathrm{~h}$. The extract was suction filtered using Whatman filter paper. This was repeated for 2 or more days and similar extracts were pooled together and concentrated at $40^{\circ} \mathrm{C}$ under reduced pressure using Buchi R-153 Rotavapor. The residual plant material was extracted successively with chloroform and methanol in the same manner as followed for hexane $[11,12]$.

\section{Thin-layer chromatography (TLC)}

Pre-coated silica gel TLC sheet (E. Merck) was used for TLC. The crude extracts were spotted at $2 \mathrm{~cm}$ from the edge of the sheet. The chromatogram was developed with a mixture of suitable solvent system and dried at room temperature. The spots were visualized with ultraviolet light at 254 and $346 \mathrm{~nm}$. The dried TLC plates were then sprayed with $10 \% \mathrm{H}_{2} \mathrm{SO}_{4}$ and heated at $110^{\circ} \mathrm{C}$ for 5 min [10]. Alternatively, the developed TLC plates were placed in iodine chamber. The $R_{\mathrm{f}}$ values of the colored spots were recorded.
Qualitative phytochemical screening

The different qualitative chemical tests were performed for establishing the profile of given extract for its chemical composition. The extracts were subjected to test for alkaloids, glycosides, carbohydrate, proteins and amino acids, phytosterols, fixed oils and fats, gums and mucilages, and volatile oil.

\section{Antimicrobial activity studies}

The concentrate of all the three extracts was tested for antibacterial activity against human pathogens.

\section{Activity against human pathogenic bacteria}

The organisms tested against were one Gram-positive and five Gramnegative aerobic bacteria. They were Escherichia coli (ATCC No25922), Klebsiella pneumoniae (ATCC No70063), Pseudomonas aeruginosa (ATCC No27853), Salmonella Typhi (ATCC No6539), Staphylococcus aureus (ATCC No25923), and Vibrio cholerae (ATCC No-24312). All the organisms had been identified and obtained from the clinical specimens in the Department of Microbiology, SRM Medical College, Chennai. Fresh

Table 1: Qualitative phytochemical screening of various extracts of Clausena dentata

\begin{tabular}{|c|c|c|c|c|}
\hline S. No. & Phytochemxical test & Hexane & Chloroform & Methanol \\
\hline \multirow[t]{5}{*}{1.} & Alkaloids & & & \\
\hline & a. Mayer's reagent & - & - & + \\
\hline & b. Wagner's reagent & - & - & + \\
\hline & c. Hager's reagent & - & - & + \\
\hline & d. Dragendorff's reagent & - & - & + \\
\hline \multirow[t]{6}{*}{2.} & Carbohydrates and glycosides & & & \\
\hline & a. Molisch's test & + & + & + \\
\hline & c. Barfoed's test & + & + & + \\
\hline & d. Benedict's test & + & + & + \\
\hline & e. Borntrager's test & + & + & + \\
\hline & f. Legal's test & + & + & + \\
\hline \multirow[t]{2}{*}{3.} & Saponins & & & \\
\hline & Foam test & - & - & - \\
\hline \multirow[t]{3}{*}{4.} & Proteins and amino acids & & & \\
\hline & a. Millon's reagent & + & + & + \\
\hline & c. Ninhydrin reagent & + & + & + \\
\hline \multirow[t]{2}{*}{5.} & Phytosteroids & & & \\
\hline & Liebermann-Burchard's test & - & - & - \\
\hline \multirow[t]{3}{*}{6.} & Fixed oils and fats & & & \\
\hline & a. Spot test & - & - & - \\
\hline & b. Saponification test & - & - & - \\
\hline \multirow[t]{6}{*}{7.} & Phenolic compounds and flavonoids & & & \\
\hline & a. Ferric chloride test & + & + & + \\
\hline & b. Gelatin test & + & - & - \\
\hline & c. Lead acetate test & + & - & - \\
\hline & d. Alkaline reagent & + & - & - \\
\hline & e. Magnesium and hydrochloric acid reduction & + & - & - \\
\hline \multirow[t]{2}{*}{8.} & Gums and mucilages & & & \\
\hline & Alcohol 95\% test & + & _ & - \\
\hline \multirow[t]{2}{*}{9.} & Volatile oils & & & \\
\hline & Steam distillation & + & + & + \\
\hline
\end{tabular}

-: Negative, +: Positive

Table 2: Effect of crude hexane extract of Clausena dentata on human pathogenic bacteria

\begin{tabular}{|c|c|c|c|c|c|c|}
\hline \multirow[t]{3}{*}{ Organism } & \multirow[t]{3}{*}{ Control } & \multicolumn{4}{|c|}{ Percentage inhibition } & \multirow[t]{3}{*}{ Antibiotic ciprofloxacin $(5 \mu \mathrm{g} / \mathrm{mL})$} \\
\hline & & \multicolumn{4}{|c|}{ Concentration of extract $(\mu \mathrm{g} / \mathrm{mL})$} & \\
\hline & & 5 & 10 & 20 & 40 & \\
\hline Escherichia coli & 8 & $11(10)$ & $12(11)$ & $18(16)$ & 21 (19) & $42(38)$ \\
\hline Klebsiella pneumoniae & 8 & $16(14)$ & $21(19)$ & $23(21)$ & $27(24)$ & $41(37)$ \\
\hline Salmonella Typhi & 8 & $12(11)$ & $14(13)$ & $18(16)$ & $23(21)$ & $42(38)$ \\
\hline Vibrio cholerae & 8 & $22(20)$ & $31(28)$ & $33(30)$ & $35(32)$ & $42(38)$ \\
\hline Staphylococcus aureus & 8 & $12(11)$ & $14(13)$ & $17(15)$ & $23(21)$ & 43 (39) \\
\hline
\end{tabular}

() Inhibition zone in mm. Values are average of three determinations 
cultures were prepared by inoculating in Mueller-Hinton (MH) broth and incubating at $37^{\circ} \mathrm{C}$ for $24 \mathrm{~h}$. Each microorganism was suspended in sterile broth and diluted to contain 106 colony-forming units (CFUs) $/ \mathrm{mL}$. This was checked by matching the turbidity of the tube with McFarland standard 0.5 of standardized bacterial suspension [13].

\section{MH broth composition for inoculation}

A loopful (4 mm diameter loop) of organism from the culture plate was added to $4.5 \mathrm{~mL}$ of sterile $\mathrm{MH}$ broth taken in a test tube. It was incubated at $37^{\circ} \mathrm{C}$ for overnight. After the incubation period, $0.5 \mathrm{~mL}$ of this bacterial suspension was added to $4.5 \mathrm{~mL}$ of sterile broth. This was incubated for $2-3 \mathrm{~h}$ at $37^{\circ} \mathrm{C}$. The turbidity was adjusted with sterile broth so as to correspond to McFarland standard 0.5.

\section{Preparation of McFarland standard (0.5)}

McFarland standard was prepared by adding $1.175 \mathrm{~g}$ of barium chloride in $100 \mathrm{~mL}$ of distilled water and $1 \mathrm{~mL}$ of $0.36 \mathrm{~N}$ sulfuric acid in $100 \mathrm{~mL}$ distilled water was prepared separately. From the McFarland standard, $99.5 \mathrm{~mL}$ of sulfuric acid and $0.5 \mathrm{~mL}$ of barium chloride were added and mixed well. It was distributed in test tubes with a screw cap of same size as those containing bacterial cultures and the turbidity was evaluated. The standard was stored in ambient temperature in the dark. The cap was closed tightly and sealed to prevent evaporation. It was agitated vigorously before use [13].
Evaluation of antibacterial activity in vitro by agar well diffusion method

MH agar medium was used for the preparation of plates; $3.8 \mathrm{~g}$ of medium was dissolved in $100 \mathrm{~mL}$ of distilled water and sterilized. The medium $(25 \mathrm{~mL})$ was poured to the depth of $4 \mathrm{~mm}$ in sterile Petri plates of $90 \mathrm{~mm}$ diameter. The agar was allowed to set at ambient temperature. In each plate, using a sterile cork borer, $8 \mathrm{~mm}$ diameter well was cut from the agar in the center of the plate. A sterile cotton swab was immersed into the standardized bacterial suspension and pressed against the wall of the tube to express excess fluid. The plates were inoculated by streaking with the swab. Streaking was done successively in three different directions to obtain even inoculum. The concentrated extracts were weighed and dissolved in dimethyl sulfoxide to prepare extract solution of conc. $1 \mathrm{mg} / \mathrm{mL}$. To each well, $5-40 \mu \mathrm{L}$ of this solution was delivered using a sterile micropipette [14]. The inoculated plates were incubated within $15 \mathrm{~min}$ of inoculation at $37^{\circ} \mathrm{C}$ for $24 \mathrm{~h}$. The plates were examined for the zone of inhibition. Inhibition zones were recorded as the diameter of growth free zones including the diameter of the well in $\mathrm{mm}$ at the end of incubation period.

\section{RESULTS}

TLC

The TLC profile of hexane, chloroform, and methanol extracts of C. dentata reveals that presence of coumarin and alkaloids.

Table 3: Analysis of variance for the effect of hexane extract of Clausena dentata on human pathogenic bacteria

\begin{tabular}{|c|c|c|c|c|c|c|c|}
\hline \multirow[t]{2}{*}{ S. No. } & \multirow[t]{2}{*}{ Extract } & \multirow[t]{2}{*}{ Organism } & \multirow[t]{2}{*}{ Concentration $(\mu \mathrm{g} / \mathrm{mL})$} & \multirow{2}{*}{$\begin{array}{l}\text { Mean inhibition } \\
\text { zone }(\mathrm{mm}) \pm S D\end{array}$} & \multirow[t]{2}{*}{$\mathbf{F}$} & \multicolumn{2}{|c|}{ 95\% CI mean } \\
\hline & & & & & & Lower & Upper \\
\hline \multirow[t]{22}{*}{1.} & Hexane & Escherichia coli & 5 & $10 \pm 1.00$ & 1018.500 & 7.52 & 12.48 \\
\hline & & & 10 & $11 \pm 1.00$ & 985.500 & 8.52 & 13.48 \\
\hline & & & 20 & $16 \pm 1.00$ & 865.500 & 13.52 & 18.48 \\
\hline & & & 40 & $19 \pm 1.00$ & 829.500 & 16.52 & 21.48 \\
\hline & & Klebsiella pneumoniae & 5 & $14 \pm 1.00$ & 904.500 & 11.52 & 16.48 \\
\hline & & & 10 & $19 \pm 1.00$ & 829.500 & 16.52 & 21.48 \\
\hline & & & 20 & $21 \pm 1.00$ & 820.500 & 18.52 & 23.48 \\
\hline & & & 40 & $23 \pm 1.00$ & 829.500 & 21.52 & 24.48 \\
\hline & & Salmonella Typhi & 5 & $11 \pm 1.00$ & 985.500 & 8.52 & 13.48 \\
\hline & & & 10 & $13 \pm 1.00$ & 928.500 & 10.52 & 15.48 \\
\hline & & & 20 & $16 \pm 1.00$ & 865.00 & 13.52 & 18.48 \\
\hline & & & 40 & $21 \pm 1.00$ & 800.500 & 18.52 & 23.48 \\
\hline & & Vibrio cholerae & 5 & $20 \pm 1.00$ & 640.00 & 17.52 & 22.48 \\
\hline & & & 10 & $28 \pm 1.00$ & 883.500 & 25.52 & 30.48 \\
\hline & & Pseudomonas aeruginosa & 5 & $9 \pm 3.00$ & 1054.500 & 6.52 & 11.48 \\
\hline & & & 10 & $11 \pm 1.00$ & 985.500 & 8.52 & 13.48 \\
\hline & & & 20 & $13 \pm 1.00$ & 928.500 & 10.52 & 15.48 \\
\hline & & & 40 & $14 \pm 1.00$ & 904.500 & 11.52 & 16.48 \\
\hline & & Staphylococcus aureus & 5 & $11 \pm 2.00$ & 985.500 & 8.52 & 13.48 \\
\hline & & & 10 & $13 \pm 2.00$ & 928.500 & 10.52 & 15.48 \\
\hline & & & 20 & $15 \pm 1.00$ & 883.500 & 12.52 & 17.48 \\
\hline & & & 40 & $21 \pm 1.00$ & 820.500 & 18.52 & 23.48 \\
\hline
\end{tabular}

All values are expressed as mean \pm SD. p<0.001 (ANOVA). Compared with control and antibiotic (ciprofloxacin). CI: Confidence interval, SD: Standard deviation, ANOVA: Analysis of variance

Table 4: Effect of crude chloroform extract of Clausena dentata on human pathogenic bacteria

\begin{tabular}{|c|c|c|c|c|c|c|}
\hline \multirow[t]{3}{*}{ Organism } & \multirow[t]{3}{*}{ Control } & \multicolumn{4}{|c|}{ Percentage inhibition } & \multirow[t]{3}{*}{ Antibiotic ciprofloxacin $(5 \mu \mathrm{g} / \mathrm{mL})$} \\
\hline & & \multicolumn{4}{|c|}{ Concentration of extract $(\mu \mathrm{g} / \mathrm{mL})$} & \\
\hline & & 5 & 10 & 20 & 40 & \\
\hline Escherichia coli & 8 & $10(9)$ & $17(15)$ & $19(17)$ & $23(21)$ & $36(40)$ \\
\hline Klebsiella pneumoniae & 8 & $9(8)$ & $12(10)$ & $17(15)$ & $22(21)$ & $41(37)$ \\
\hline Salmonella Typhi & 8 & $12(11)$ & $14(13)$ & $20(18)$ & $23(21)$ & $36(38)$ \\
\hline Vibrio cholerae & 8 & $28(25)$ & $31(34)$ & $35(32)$ & $32(34)$ & $36(40)$ \\
\hline Staphylococcus aureus & 8 & $11(10)$ & $13(12)$ & $17(15)$ & $22(20)$ & $36(40)$ \\
\hline
\end{tabular}

() Inhibition zone in mm. Values are average of three determinations 
Table 5: Analysis of variance for the effect of chloroform extract of Clausena dentata on human pathogenic bacteria

\begin{tabular}{|c|c|c|c|c|c|c|c|}
\hline \multirow{2}{*}{ S. No. } & \multirow{2}{*}{ Extract } & \multirow[t]{2}{*}{ Organism } & \multirow[t]{2}{*}{ Concentration $(\mu \mathrm{g} / \mathrm{mL})$} & \multirow{2}{*}{ Mean inhibition zone $(\mathrm{mm}) \pm S D$} & \multirow[t]{2}{*}{$\mathbf{F}$} & \multicolumn{2}{|c|}{ 95\% CI mean } \\
\hline & & & & & & Lower & Upper \\
\hline \multirow[t]{22}{*}{1.} & Chloroform & Escherichia coli & 5 & $9 \pm 1.00$ & 664.900 & 6.52 & 11.48 \\
\hline & & & 20 & $17 \pm 1.00$ & 537.700 & 14.52 & 19.48 \\
\hline & & & 40 & $21 \pm 2.00$ & 688.900 & 18.52 & 23.48 \\
\hline & & Klebsiella pneumoniae & 5 & $8 \pm 1.00$ & 642.200 & 5.52 & 10.48 \\
\hline & & & 10 & $10 \pm 2.00$ & 655.200 & 7.52 & 12.48 \\
\hline & & & 20 & $15 \pm 1.00$ & 558.700 & 12.52 & 17.48 \\
\hline & & & 40 & $21 \pm 1.00$ & 575.700 & 18.52 & 23.48 \\
\hline & & Salmonella Typhi & 5 & $11 \pm 1.00$ & 622.300 & 8.52 & 13.48 \\
\hline & & & 10 & $13 \pm 2.00$ & 586.900 & 10.52 & 15.48 \\
\hline & & & 20 & $18 \pm 1.00$ & 529.900 & 15.52 & 20.48 \\
\hline & & & 40 & $21 \pm 1.00$ & 517.300 & 18.52 & 23.48 \\
\hline & & Vibrio cholerae & 5 & $25 \pm 3.00$ & 525.700 & 22.52 & 27.48 \\
\hline & & & 10 & $31 \pm 1.00$ & 592.300 & 28.52 & 33.48 \\
\hline & & & 20 & $32 \pm 3.00$ & 609.700 & 29.52 & 34.48 \\
\hline & & Pseudomonas aeruginosa & 5 & $9 \pm 1.00$ & 850.875 & 6.52 & 11.48 \\
\hline & & & 10 & $10 \pm 1.00$ & 642.700 & 7.52 & 12.48 \\
\hline & & & 20 & $11 \pm 1.00$ & 769.375 & 9.90 & 12.77 \\
\hline & & & 40 & $13 \pm 1.00$ & 928.500 & 10.52 & 15.48 \\
\hline & & Staphylococcus aureus & 5 & $10 \pm 1.00$ & 642.700 & 7.52 & 12.48 \\
\hline & & & 10 & $12 \pm 1.00$ & 603.700 & 9.52 & 14.48 \\
\hline & & & 20 & $15 \pm 1.00$ & 558.700 & 12.52 & 17.48 \\
\hline & & & 40 & $20 \pm 1.00$ & 519.700 & 17.52 & 22.48 \\
\hline
\end{tabular}

All values are expressed as mean \pm SD. $p<0.001$ (ANOVA). Compared with control and antibiotic. CI: Confidence interval, SD: Standard deviation, ANOVA: Analysis of variance

Table 6: Effect of crude methanol extract of Clausena dentata on human pathogenic bacteria

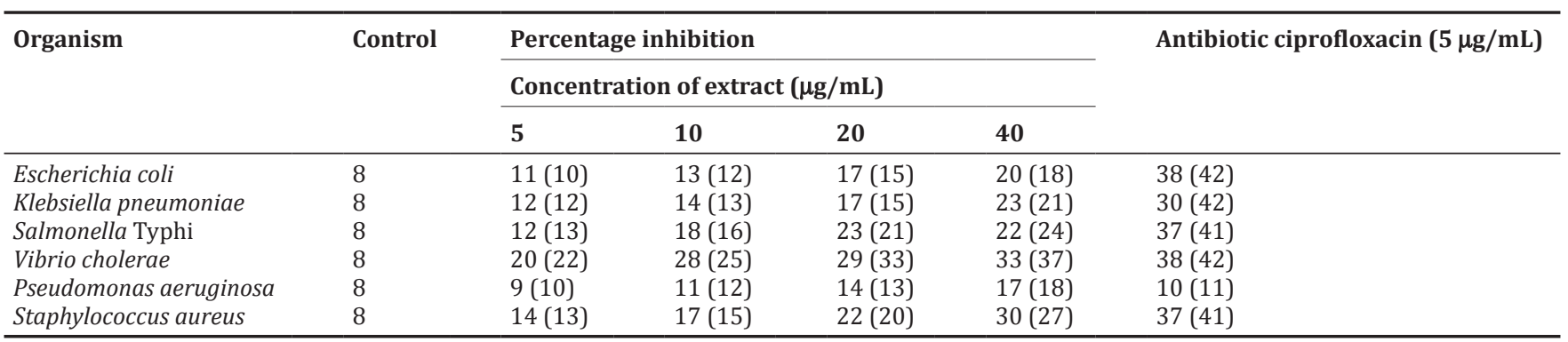

() Inhibition zone in mm. Values are average of three determinations

\section{Qualitative phytochemical screening}

Qualitative chemical tests revealed the presence of various phytochemicals in hexane, chloroform, and methanol extracts of C. dentata (Table 1). The methanol extract showed positive test for alkaloids. All the extracts contained carbohydrates, glycosides, amino acids, proteins, and volatile oils. Ferric chloride test showed the presence of phenolic compounds, in all the extracts. Saponins, phytosteroids, fixed oils, and fats were absent.

\section{Antibacterial activity of the extracts of $C$. dentata on human pathogenic bacteria}

The antibacterial activities of the extracts of hexane, chloroform, and methanol are presented in Tables 2-7. The hexane, chloroform, and methanol extracts showed significant antibacterial activity against E. $\operatorname{coli}(21,23$, and $20 \%$ inhibition at $40 \mu \mathrm{g}$ of hexane, chloroform, and methanol extract of $C$. dentata), Salmonella Typhi $(23,23$, and 24\%), $K$. pneumoniae $(27,22$, and $23 \%), V$. cholerae $(35,37$, and $37 \%)$, and $S$. aureus $(23,20$, and $30 \%)$. They are more active against $V$. cholerae. The activity against $P$. aeruginosa was mild.

\section{DISCUSSION}

In the present-day context, the synthetic drugs have proved to result with numerous side effects. This situation has clearly created awareness in the global arena to concentrate on the area of research from plant products. Important plant secondary metabolites known as glycosides, flavonoids, coumarins, lignins, terpenoids, and alkaloids have been isolated over a period of time from natural sources. Coumarins have a variety of bioactivities including anticoagulant, estrogenic, dermal photosensitizing, antimicrobial, vasodilator, molluscacidal, anthelmintic, sedatives and hypnotic, analgesic, anti-inflammatory, and hypothermic activity [15].

Since Clausena species contain coumarin derivatives and carbazole alkaloids, an attempt has been made to isolate the pure coumarin derivatives and carbazole alkaloid from the crude material of $C$. dentata. Hexane, chloroform, and methanol extracts were taken from stem bark of $C$. dentata. The hexane, chloroform, and methanol extracts were tested for antibacterial activity against human pathogenic bacteria in the present study.

The organisms tested against were one Gram-positive and five Gram-negativeaerobic bacteria. TheywereS.aureus, E.coli, K. pneumoniae, P. aeruginosa, Salmonella Typhi, and Vibrio cholerae. The efficacy of plant extracts and isolated compounds as effective antibacterial agents was tested and compared with an antibiotic ciprofloxacin. Ciprofloxacin is a fluoroquinolone that is active against both Gram-negative and positive bacteria [16]. Have been reported that the free $6-\mathrm{OH}$ in the courmarin 
Table 7: Analysis of variance for the effect of methanol extract of Clausena dentata on human pathogenic bacteria

\begin{tabular}{|c|c|c|c|c|c|c|c|}
\hline \multirow[t]{2}{*}{ S. No. } & \multirow[t]{2}{*}{ Extract } & \multirow[t]{2}{*}{ Organism } & \multirow[t]{2}{*}{ Concentration $(\mu \mathrm{g} / \mathrm{mL})$} & \multirow[t]{2}{*}{ Mean inhibition zone $(\mathrm{mm}) \pm S D$} & \multirow[t]{2}{*}{$\mathbf{F}$} & \multicolumn{2}{|c|}{$95 \%$ CI mean } \\
\hline & & & & & & Lower & Upper \\
\hline \multirow[t]{22}{*}{1.} & Methanol & Escherichia coli & 5 & $10 \pm 1.00$ & 1446.00 & 7.52 & 12.48 \\
\hline & & & 20 & $15 \pm 1.00$ & 1273.500 & 12.52 & 17.48 \\
\hline & & & 40 & $18 \pm 3.00$ & 1368.000 & 25.52 & 30.48 \\
\hline & & Klebsiella pneumoniae & 5 & $12 \pm 1.00$ & 1206.000 & 9.52 & 14.48 \\
\hline & & & 10 & $13 \pm 1.00$ & 1333.500 & 10.52 & 15.48 \\
\hline & & & 20 & $15 \pm 3.00$ & 1273.500 & 12.52 & 17.48 \\
\hline & & & 40 & $21 \pm 1.00$ & 1165.500 & 18.52 & 23.48 \\
\hline & & Salmonella Typhi & 5 & $12 \pm 1.00$ & 1368.000 & 9.52 & 14.48 \\
\hline & & & 10 & $16 \pm 1.00$ & 1248.000 & 13.52 & 18.48 \\
\hline & & & 20 & $21 \pm 2.00$ & 1166.500 & 18.52 & 23.48 \\
\hline & & & 40 & $22 \pm 1.00$ & 1158.000 & 19.52 & 24.48 \\
\hline & & Vibrio cholerae & 5 & $20 \pm 1.00$ & 1176.000 & 17.52 & 22.48 \\
\hline & & & 10 & $25 \pm 2.00$ & 1153.500 & 22.52 & 27.48 \\
\hline & & & 20 & $9 \pm 1.00$ & 1189.500 & 26.52 & 31.48 \\
\hline & & Pseudomonas aeruginosa & 5 & $10 \pm 1.00$ & 1446.000 & 7.52 & 12.48 \\
\hline & & & 10 & $11 \pm 1.00$ & 985.500 & 8.52 & 13.48 \\
\hline & & & 20 & $13 \pm 1.00$ & 1333.500 & 10.52 & 15.48 \\
\hline & & & 40 & $14 \pm 1.00$ & 904.500 & 11.52 & 16.48 \\
\hline & & Staphylococcus aureus & 5 & $13 \pm 1.00$ & 1350.000 & 10.52 & 15.48 \\
\hline & & & 10 & $15 \pm 1.00$ & 1273.000 & 12.62 & 17.48 \\
\hline & & & 20 & $20 \pm 2.00$ & 1176.000 & 17.52 & 22.48 \\
\hline & & & 40 & $27 \pm 1.00$ & 1165.000 & 24.52 & 24.48 \\
\hline
\end{tabular}

All values are expressed as mean \pm SD. p $<0.001$ (ANOVA). Compared with control and antibiotic. CI: Confidence interval, SD: Standard deviation, ANOVA: Analysis of variance

nucleus has been found to be an important one for antibacterial activity. Since all the 3 extracts are containing phenolic compounds responsible for antibacterial activity against human pathogen. Since $C$. dentata shows good antibacterial activity, further studies required in the isolated compounds and formulation level.

\section{CONCLUSION}

The hexane, chloroform, and methanol extracts showed significant antibacterial activity against E. coli, Salmonella Typhi, K. pneumoniae, $V$. cholerae, and $S$. aureus. The activity against $V$. cholerae was comparable with that of $5 \mu \mathrm{g} / \mathrm{mL}$ ciprofloxacin at the concentration of $C$. dentata 40 $\mu \mathrm{g} / \mathrm{mL}$. The orders of antibacterial activity against human pathogenic bacteria are hexane, methanol, and chloroform extract of $C$. dentata. The activity against $P$. aeruginosa was mild.

\section{ACKNOWLEDGMENT}

The authors acknowledge Prof. N. Raman, Centre for Advanced Studies in Botany, University of Madras, for continuous support throughout the project.

\section{AUTHORS' CONTRIBUTIONS}

Raju Kamaraj performed the preparation and analysis of extract. Annmalai Maduram contributed to design of the experiment and manuscript writing.

\section{CONFLICTS OF INTEREST}

We declare that we have no conflicts of interest.

\section{REFERENCES}

1. Chopra RN, Nayar SL, Chopra IC. Glossary of Indian Medicinal Plants. New Delhi, India: Council of Scientific and Industrial Research; 1956. p. 246.
2. Kirtikar KR, Basu BD, Singh B. Indian Medicinal Plants. Dehradun, India: M/s Bighensing Mahendra Palsingh Publishers; 1980. p. 2793.

3. Rao S, Subramanian KS. Isolation of $\alpha, \beta$ and $\gamma$-clausenan and diclausenan from Clausena willdenovii. Proc Indian Acad Sci $1936 ; 3: 31$.

4. Govindachari TR, Pai BR, Subramaniam PS, Muthukumaraswamy N. Coumarins of Clausena dentata. Tetrahedron Lett 1968;24:753-7.

5. Rao GS, Rao K, Ravindranath B. Structure of diclausenan A and B. Tetrahedron Lett 1976;13:1019-20.

6. Matern U, Luer P, Kreusch D. Biosynthesis of coumarins. Polyketides and other secondary metabolites including fatty acids and their derivatives. In: Barton D, Nakanishik K, Meth-Cohn O, Sankawa U, editors. Comprehensive Natural Products Chemistry. Vol. 1. Oxford, UK: Elsevier Science Ltd.; 1999. p. 623-7.

7. Yang YZ, Ranz A, Pan HZ, Zhang ZN, Lin XB, Meshnick SR. Daphnetin: A novel antimalarial agent with in vitro and in vivo activity. Am J Trop Med Hyg 1992;46:15-20.

8. Yenjai C, Sripontan S, Prajun PS, Kittakoop P, Jintasiriknl A, Tanticharoen M, et al. Coumarins and carbazoles with antiplasmodial activity from Clausena harmandiana. Planta Medica 2000;66:277-9.

9. Ananthanarayanan R, Paniker CK. Text book of Microbiology. India: Orient Longman; 1999. p. 612.

10. Hammond SM, Peter PA. Antibiotics and Antimicrobial Action. London: Edward Arnold Publishers Ltd.; 1978. p. 200.

11. Harborne JB. Phytochemical Methods: A Guide to Modern Techniques of Plant Analysis. London: Chapman and Hall Publishers; 1988. p. 278.

12. Harborne JB. Phytochemical Methods: A Guide to Modern Techniques of Plant Analysis. London: Chapman and Hall Publishers; 1998. p. 293.

13. Sundararaj T. Microbiology Laboratory Manual. Chennai, India: University of Madras; 1996. p. 50.

14. Perez C, Pauli M, Bazerquw P. An antibiotic assay by the agar well diffusion method. Acta Biol Med Exp 1990;15:113-5.

15. O'Kennedy R, Thrones R. Coumarins Biology, Applications and Mode of Action. Chickester, UK: John Wiley and Sons Ltd.; 1997. p. 270.

16. Sardari S, Mori Y, Horita K, Micetih R, Nishibe G, Daneshtalab Y. Synthesis and antifungal activity of coumarins and angular Furano coumarins. Bioorg Med Chem 1999;7:1933-40. 